\title{
1. Introduction: the need to rethink environmental laws
}

\author{
Rose-Liza Eisma-Osorio, Elizabeth A. Kirk \\ and Jessica Steinberg Albin
}

\section{INTRODUCTION}

It might seem an odd point in time to write an introduction to a book of success stories in environmental law. There are a growing number of strikes by schoolchildren around the world as they protest the lack of action to tackle climate change. There are more and more reports of environmental harm. The Intergovernmental Science-Policy Platform on Biodiversity and Ecosystem Services (IPBES) Summary for Policymakers of the global assessment report on biodiversity and ecosystem services released in $2019^{1}$ revealed the devastating scale of loss of biodiversity across the world. The report notes that approximately 1 million animal and plant species are threatened with extinction, despite global and national laws on conservation and sustainable use of biodiversity. Again, despite our global commitments to tackling greenhouse gasses, the report notes that since 1980, emissions have doubled and global temperatures have continued to rise; and by 2015, despite a myriad of laws on fishing, only 7 per cent of fish stocks were harvested at sustainable levels. Underpinning much of this bad news is that around three-quarters of all land has been changed to a significant degree by human actions. The findings of the IPBES report are reiterated in other documents, such as the 2019 Global Environmental Outlook Report. ${ }^{2}$

1 Intergovernmental Science-Policy Platform on Biodiversity and Ecosystem Services, Summary for policymakers of the global assessment report on biodiversity and ecosystem services of the Intergovernmental Science-Policy Platform on Biodiversity and Ecosystem Services, advance unedited version, 6 May 2019, available at www.ipbes.net/news/ipbes-global-assessment-summary-policymakers-pdf.

2 UN Environment (2019), Global Environment Outlook - GEO-6: Summary for Policymakers, Nairobi. 
It is clear that there is a need for a radical rethink of the content and role of environmental laws at a global scale and within individual countries. Where, though, do we start?

The 15th Annual Colloquium of the International Union for the Conservation of Nature Academy of Environmental Law was held in Cebu, the Philippines - a country rich in biodiversity, specifically forest and marine habitats. At the same time, the Philippines - like most, if not all, countries - faces real challenges in protecting its natural resources. It is known around the world, however, for its environmental law success stories, such as the landmark Oposa decision, ${ }^{3}$ in which the rights of minors to sue were recognized by the Supreme Court using the principle of intergenerational responsibility. The success stories from the Philippines remind us that there are stories in different parts of the world where environmental law has actually made things better, and that these should be shared with a view to promoting further environmental law successes around the world. Such stories include successes in public and stakeholder engagement, such as those seen in the management of the Lake Champlain watershed in the north-eastern United States, where governmental actors, environmental advocates, farmers, loggers and developers in Vermont reached an agreement on a basin-wide, 20-year plan and process for restoring the watershed. South Australia has also adopted successful legislation to increase the use of renewable energy and significantly reduce greenhouse gas emissions. Other examples include non-governmental organization (NGO) activists such as Forever Sabah promoting a circular economy through projects which demonstrate a narrative of moving from the 'downstream' to the 'upstream' to support the state's transition towards a diversified, equitable and circular economy. States, too, have taken successful action - such as Taiwan's comprehensive recycling strategy and policies which have become institutionalized at household, municipal and national levels.

In this volume, we present some environmental law success stories from around the world - laws, regulations, policies and incentives which have resulted in positive environmental outcomes in all areas of environmental law.

\section{GLOBAL AND NATIONAL SUCCESS STORIES}

Following an inspirational foreword from Antonio Oposa, we begin with Robert Percival's account of the global phase-out of lead in gasoline, which is one of the greatest success stories in the history of environmental law. Percival outlines the role of scientists, public health advocates, judges and public interest lawyers in this phase-out. The estimated phase-out is producing between $\$ 2$

$3 \quad$ G.R. No. 101083, 30 July 1993. 
trillion and $\$ 3$ trillion in net benefits for public health globally each year. The chapter reviews the history of this success story to elicit lessons for promoting future advances in law and public policy.

From there, we examine another global issue in Trevor Daya-Winterbottom's chapter on caring for our oceans and their biodiversity. While focusing on initiatives in a single state - New Zealand's national strategies for oceans governance - this contribution examines how international environmental law obligations are implemented through both vertical comparison with the international legal order and horizontal comparison between jurisdictions. It concludes that while there are clear gaps in implementation, there is dynamic commitment from states to experiment with new legal and policy responses, and real opportunities to learn from this experience about what works and why. The contribution fits within a wider global narrative of dynamic commitments from individual states. For example, the Philippine Constitution provides for the protection of the rights of subsistence fishermen. Too often, such commitments are merely paper promises; but the Philippines has followed this up with Fisheries Administrative Order 246, which bans the destructive Danish and modified Danish seine - fishing methods that scrape the bottom of the sea and catch everything in their way. This policy should ensure the intergenerational sustainability of fishery resources.

The volume then turns to consider further national issues, beginning with Nicholas Robinson's lessons from the Charter of the Forest. Robinson draws lessons from the Charter of the Forest adopted in England in 1217, demonstrating that it offers perhaps the best-documented account of how society can chart the resilient care of large natural areas over many eras - in this case, from the medieval era to the Anthropocene. The story of how the Charter of the Forest has conserved a biome and provided effective protection over many generations provides guidance for preserving other natural areas (e.g., marine protected areas). The lessons from the Charter of the Forest have echoes in international law. For example, the adoption of the Convention for the Safeguarding of the Intangible Cultural Heritage in 2003 prompts a reconsideration of how the environment is protected. Key to this is a focus on preserving intangible aspects of heritage, including skills and spaces used by indigenous and local communities. In some ways, this Convention reflects aspects of the Charter of the Forest. For example, the Charter protects traditional use rights. Similarly, the Convention enables protection of traditional uses, such as the traditions and practices associated with the Kayas in the sacred forests of the Mijikenda in Kenya, inscribed in 2009 in the United Nations Educational, Scientific and Cultural Organization List of Intangible Cultural Heritage in Need of Urgent Safeguarding, which contributes to the preservation of the ecosystem. These rights are being protected by the Kenyan Department of Culture in collaboration with the Mijikenda communities and the Coastal Forest 
Conservation Unit and Kenya Forest Service, through innovative policies such as replanting trees in sacred Kaya forests to prevent deforestation and cultural measures such as education.

\section{NEW APPROACHES IN ENVIRONMENTAL LAW}

These lessons are also worth considering in light of new approaches to rights both to and of nature. For example, the Ecuadorian Constitution provides that nature itself is a legal subject and has legally enforceable rights ${ }^{4}$ and rights have been granted to rivers in New Zealand, ${ }^{5}$ India $^{6}$ and Bangladesh ${ }^{7}$ through recent cases. Elsewhere, a constitutional duty or right to protect the environment has been introduced. ${ }^{8}$ Reviewing the Charter of the Forest provides an opportunity for comparison of the enduring rights granted in the Charter with these newer rights and tools to protect nature.

From rights in forests, we move on to consider another type of area-based management, with Estrin, Phillips and Adimazoya's contribution on the protection of the Sakumo Lagoon in Ghana under the Ramsar Convention. The authors examine the link between formal national measures and traditional governance measures in protecting this lagoon, and draw lessons on wetlands management through comparisons with other states. They highlight the need for concrete measures to bridge governance gaps and make co-management of wetlands a reality, and for localized incentives for conservation and restoration. Again, the issues they examine are resonant of wider issues. The challenges of integrating different governance approaches are echoed in work to

4 Tanasescu M. (2016) 'The Rights of Nature in Ecuador' in Environment, Political Representation, and the Challenge of Rights (London: Palgrave Macmillan).

5 Te Awa Tupua (Whanganui River Claims Settlement) Act 2017 Public Act 2017 No. 7, date of assent 20 March 2017.

${ }_{6}$ However, this ruling was subsequently overturned by the Supreme Court. India's Ganges and Yamuna rivers are 'not living entities' (BBC News, 27 July 2017); www.bbc.com/news/world-asia-india-40537701, last accessed 23 July 2019.

7 Antara, N. (2019) 'Turag given "legal person" status to save it from encroachment', Dhaka Tribune, 30 January; www.dhakatribune.com/bangladesh/court/2019/ 01/30/turag-given-legal-person-status-to-save-it-from-encroachment, last accessed 23 July 2019.

8 Daly, E. (2012) 'Constitutional Protection for Environmental Rights: The Benefits of Environmental Process', International Journal of Peace Studies, vol 17, no 2, 2012, pp71-80. JSTOR, www.jstor.org/stable/41853036, last accessed 23 July 2019. 
manage cross-border preserves - particularly those found in areas of conflict, ${ }^{9}$ such as between the two Koreas. ${ }^{10}$

\section{SUSTAINABLE SOLUTIONS IN ENVIRONMENTAL LAW}

We then turn to alternative ways of tackling existing issues. Foerster demonstrates the benefits of ecosystem-based approaches compared to conventional Australian approaches to climate adaptation and disaster risk reduction. This chapter provides a further opportunity to reflect on what is meant by success. Although success as generally understood takes the form of 'transformation', this chapter - through comparative case studies and a tentative Australian move towards a similar direction - provides a spectrum of success that includes process success, substantive success, transformative success and ultimate success. In this chapter, Foerster also highlights the dangers of short-term infrastructure solutions, as compared to a more rounded and longer-term view of the links between human and ecological elements of various systems encapsulated by the ecosystem approach. As she demonstrates, low-tech solutions such as maintaining vegetation cover in riparian zones and preserving natural floodplains can minimize flood risks substantially. Lye Lin-Heng continues this discussion of alternative, potentially more sustainable approaches with her review of Singapore's approach to housing. While some may assume that housing and the environment are separate issues, Lye demonstrates that a national approach to planning, which allows the government to support the development of energy-efficient housing with integrated green spaces, can have significant environmental benefits. The approach taken in Singapore is at odds with much of the world: around 80 per cent of the population live in housing leased (often on 99-year leases) from the national housing board. It is this concentration of the leasehold in the hands of a national body that makes quickly responding to environmental challenges through housing policy relatively simple and successful.

These issues of land use management are playing out around the world in different contexts. The 2004 Brazilian Action Plan for the Prevention and Control of Deforestation in the Amazon, for example, has led to a 60 per cent reduction in deforestation. In other countries, court cases have reviewed

9 Hsiao, E. (2018) 'Nomoscaping Peace in Times of Conflict: A Case Study of the Greater Virunga Transboundary Collaboration (GVTC)', 9 IUCN Academy of Environmental Law eJournal 79-103.

10 www.theguardian.com/environment/2012/apr/13/wildlife-thriving-korean -demilitarised-zone. 
the need for environmental impact assessments ${ }^{11}$ and their relationship to the precautionary principle. ${ }^{12}$

\section{ROLE OF COURTS AND CITIZENS IN ENFORCING ENVIRONMENTAL LAWS}

Finally, we turn more fully to the role of courts and questions of enforcement and monitoring more generally. Pickering and Lin's contribution assesses the impact of the Taizhou public interest case in China on environmental enforcement. The case is significant in two ways. Most obvious is the amount of damages awarded. At RMB 160 million (\$26 million), the award is the largest award for damages in Chinese environmental public interest litigation. The decision also demonstrates the strengthened roles of the procuratorates, the courts, NGOs and citizens in holding actors accountable for stewardship duties. The chapter raises a number of issues that are found in other jurisdictions. Public interest litigation, for example, is on the rise in countries such as Australia, where the New South Wales Environmental Defenders Office (EDO NSW) has been active in strengthening environmental laws through important precedent-setting cases. The result there, however, has been the government's withdrawal of the EDO NSW's funding.

In other countries, too, courts are taking decisions which will strengthen protection of the environment. For example, in South Africa, Abbott $v$ Overstrand Municipality \& 3 Others (2016) saw the Supreme Court find in favour of ecosystem flows, where previously it would have found in favour of the property holder. Similarly, a range of actors are becoming more important in the protection of our environment. These include Indonesia's National Movement in Rescuing Indonesia's Natural Resources, initiated by the Corruption Eradication Commission in 2015 to eradicate corruption in Indonesia's natural resource management.

Elsewhere, other innovative approaches are being taken to enforcement. For example, the European Union's yellow card issued to the Philippines in 2014 led the government to amend the Fisheries Code of 1998 to impose vessel monitoring measures to improve monitoring and enforcement. ICJ 14.

1 Case Concerning Pulp Mills on the River Uruguay (Argentina v Uruguay), 2010

12 www.businesslive.co.za/bd/companies/energy/2018-08-22-thabametsi-and -khanyisa-coal-fired-plants-must-have-latest-emissions-technology-says-radebe/. 


\section{IN SUMMARY}

As we hope this introduction demonstrates, the chapters in this volume provide a snapshot of developments around the world which represent success stories in the management and protection of our environment. This volume will show how stories of good practices around the world can be used not only to illustrate the 'bright spots', but also to help those who may be facing challenges to identify important lessons. There is more - much more - to be done if we are to ensure a sustainable future; but these stories remind us that it is possible to take positive action towards a better, more sustainable relationship between society and the environment. 